\title{
MILITARY IDENTITY
}

\author{
Robert PRODANCIUC \\ University of Petroșani, Romania \\ robertprodanciuc@yahoo.co.uk
}

\begin{abstract}
This paper is aimed at exploring the process of military identity acquisition. In order to be able to do this, it is important to define the concepts of institution and organization with reference to the social subsystem represented by the army. The analysis of the aspirants to the status of member of the army was done through the systemic and action paradigms, as well as the praxiological vision. Individuals wishing to integrate into the military system are analysed from a four-dimensional perspective, that is to say, from the point of view of the four defining aspects of each individual: biological, psychological, social and cultural. We also think that it is very important to address the responsibilities of the manager, in our case the commander, regardless of the level of the commanded formation. In the unfortunate case where the results do not meet the expectations, there are competent specialists who can provide the necessary support, not only military, but also civilians, and their specialization isn't restricted to the field of psychology.
\end{abstract}

\section{Keywords: identity, military, army}

\section{Introduction}

Humans, like many other beings of various species, have the instinctive habit of wanting and even appropriating something of what others have and they lack. This happens at both individual and collective level. The act of appropriating the property of another is done only if it is possible, that is, if the predator possesses extra force and aggression, and the robbed manifests weakness and fear. In the extreme, it can even get to the dispossession of vital space and the loss of the life of the robbed. From the primitive horde to the modern state, the tendency of robbing neighbours, individually or collectively, exists and manifests when the aggressor sees the slightest chance of success. At the same time, the assaulted attempts to discourage and/or to stop the plunderous action. To this end, resorting to appropriate ways of reacting can range from negotiation to violent defence. As such, there is a need to ensure the most effective security of life and stability of property, i.e., the institution appears and manifests itself [1]. In our case, it is the military institution, as a social structure of force, acting to defend the society from possible external aggressions.

\section{Conceptual Delimitations}

Next, it is necessary to approach military organizations represented by the army. For a more complete understanding of the organization, in general, and the army, in particular, a review of the organization definitions is required. They are partially complementary according to several authors, both Romanian and foreign. Thus, organizations are seen as "formal organizational structures to which people adhere freely, optionally, according to their individual or collective interests" [2], or they are "ordered and hierarchical human 
assemblies in order to cooperate and coordinate their members for certain purposes" [3], or "the organization is a rational, institutionalized form of interaction of a group of persons justified by the interest (or the pretext) in achieving a certain common goal" [4], or "organizations are social institutions created by individuals or groups in society to achieve specific goals through the means of forecasting, organizing, coordinating, training and controlling activities" [5] and finally "an organization is an institution that has specific features like: a) involves the voluntary membership of its members; b) involves a relatively specialized activity; c) its content refers to its members, although it can also work with other individuals representing their field of specialized activity; d) it is relatively autonomous in its birth and functioning" [6].

Once we have gone through these definitions written by authors of different professions, we can try our own synthesis. Thus, we define the army as the societal subsystem created by society and made up as an institutional-organizational ensemble to which individuals adhere freely, according to their immediate or lasting interests, accept ordering and hierarchy, understand to co-operate and coordinate their activity with the others comrades according to the specifics of the organization, in order to defend society through the means of forecasting future events, and training in order to obtain maximum potential. All this is subject to the observance of the legal rules related to establishment and functioning of the subsystem. This definition contains the main notions of the army concept. The whole approach undertaken in this paper fully corresponds to systemic and action paradigms, as well as to the praxiological approach.

The above-mentioned definition highlights two distinct entities, between which there is a univocal relationship of belonging: the military as a constituent element, and the army as a comprehensive societal subsystem. A person, in order to become a member of the army, i.e., military, must be driven by interests designed for varying time periods. Thus, individual interests are not necessarily convergent with the interest of the army. Thus, the military can target a certain kind of identity and a personal development corresponding to it. The army, on the other hand, is interested in achieving the results corresponding with what it offers as achievement possibilities, less individual and more collective. Both identities, the individual and the collective one, are social identities.

\section{Identity Analysis}

In addressing identity in general, and the military one, in particular, it must be taken into account that man is a four-dimensional being: bio-psycho-social-cultural.

We appear in the world as "biologically unique" [7] and "everybody tells the world his biological truth, which is only his" [8]. In addition, "because we are genetically different, we are genetically unequal" [9], an assertion that should be taken into account in the recruitment process of the military. Individual diversity requires that "individuals must have equal opportunities to develop and participate to the progress of their own community, but it is certain that they will do it differently" [10]. This remark also refers to the fact that individual diversity manifests in preparation and evaluation. But, to be well understood, individuality not only does not exclude similarity, it even implies it. Each one of us resembles the others, because we all have the same nature, and similarity matters as much as individuality. Similarity allows the association of individuals within military formations.

At birth, the first question related to the child refers to its gender. In time, later on, gender identification is revealed. It means "personal identification as a man or woman" [11]. The body, as such, will develop differently under different 
environmental conditions and will change over time [12]. In connection with all this, there is a very serious warning, i.e. "the environment cannot do more than heredity allows" [13]. That is, "heredity conditions (...) only the limits [and] reaching the maximum values depends on the existence of a favourable environment" [14]. In other words, let no one hope that transformational miracles can be made about individuality.

It is known that "each one of us is psychologically unique, with one's ability to respond to environmental demands, one's reactive potential, and creative performance" [15]. The direct consequence of this is that two people on a mission may be in incompatibility, compatibility or complementarity situations. In order to ensure the optimal, not ideal situation, a good knowledge of the two is necessary, and the role of the competent specialists in realizing and providing it is essential for the achievement of the action convergence.

From a theoretical point of view, it is very difficult to define, characterize and structure the psyche and, therefore, the related knowledge is difficult to use. Without going into the depth of these problems, which is the privilege of psychologists, it should be noted that in the current approach of the individual, personality is analysed as the main component. For the needs of this work, we prefer to accept the definition of personality as being "what characterizes and differentiates a person from another" [16]. There is no agreement on the personality components either. Thus, we find that it is "the ensemble of affective, emotional, dynamic characteristics, that are relatively stable and general of a person's way of reacting to certain situations in which one might find oneself" [17]. In other works, three functional quasi-independent subsystems are considered, namely: temperament, character and aptitude [18]. We believe that the way out of the cognitive impasse consists in considering both variants as equally valid and usable for ensuring the recruitment, military training and assessment. In addition, it is necessary to know that there are adequate tests for all these components, and the military, candidate or active, can be known with the profile resulted from the test results.

The two entities, the military and the army, relate to each other through what the mathematical theory of the crowds calls the relationship of belonging. In sociology we talk about status and role. Identification, on site, is done through a service card, and more obscure, but more relevant, is given by colleagues, superiors and assessors. This means that identification "tends to depend on the other, the one who grants it" [19]. Here, we only refer to identity related to profession, but each individual has identities related to gender, age, civil status, environment, etc. It is a matter of agreement that everyone should assume their individual identity. Collective identity also occurs in a similar way. It is obvious that each identity, individual or collective implies a temporal growth, which means that "identity can only be understood as a process" [20].

At this point of argumentation, we must show that both types of identity are social by genesis as well as by manifestation. In order to circumscribe the content of the identity concept as accurately as possible, it should be noted that it refers to the ways in which it acts: a) individuals between themselves within the community; b) individuals with the community which they belong to; c) the belonging community to other communities. These relationships are systematic and mean both similarity and difference [21]. Thus, from the perspective of the individual, the community becomes for him the space-time frame of interaction with the other comrades according to the specific rules [22]. In these interactions, everyone's competences are mobilized and highlighted. As a result, each one creates a self-image and projects a personal image to the others. These images can be congruent or not. The actions of a person and their 
own image can bring satisfaction or anxiety. But not less important is the labelling of each other [23].

From the acceptance of a person in the military unit to their full integration into the unit, each military has to go through several stages, such as: prior information, adjustment to the organization, and its requirements and managing the internalized role in which the activity and results obtained by evaluation matter [24]. In general, people employed in various organizations cannot integrate by themselves, but they need both support and strategies, as well as programs specific to the organization. This is how the "reciprocal adjustment process between the individual and the organization" is accomplished [25]. Performance is "the result of the motivated individual's effort" and "is assessed by the degree to which the objectives are met" [26].

At this point, the economic perspective of identity should be approached. From this perspective, the identity of the people in general and, therefore, of the military, refers to: a) social categories (soldiers, officers, generals and admirals); b) the rules associated with each category and c) the individual gains and losses suffered as a result of decisions and actions [27]. As a result, the individual maximizes their utility function, as an insider "when adhering to the rules of the category to which one belongs" [28]. One minimizes their utility function when one departs from these rules as an outsider. In the army, military identity means implicit adherence to its objectives, acceptance of specific socialization, obedience to order, pride of distinct identity and sense of personal involvement through the tasks received and devaluation of material rewards in favour of symbolic ones [29].

The cultural dimension of the human being refers to the knowledge, the skills, the values and the behaviour patterns one acquired through socialization. The organizational culture is part of the general culture. It refers to "the way in which work is done and people relate" [30]. It has the following characteristics: 1) forms a whole; 2) reflects the organization's situation at various moments in time; 3 ) is created and maintained by the members of the organization and 4) is experienced differently by the members of the organization [31]. Its cohesiveness determines the strength of the organization and therefore attempts to improve it are continuously made.

\section{Conclusions}

The most important factor in creating, maintaining and changing the organization is the manager or the commander, from the smallest to the largest unit size. It is well known and acknowledged that in organizations in general, and in the state patronized ones, in particular, the persons that are being promoted don't really correspond to the job description because they have a very poor managerial training. What they do not know or know little about is how to "get the maximum performance from the people they lead" [32]. Although this is an economic perspective, it fits perfectly into the military environment.

According to this point of view, the main task of a responsible commander is to obtain the maximum results, which must be well defined. However, here lies the real danger of overworking subordinates. The next responsibility of the commander is the retention of the subordinates, especially when they have volunteered. Any departure motivated by the commander's mistakes is costly, because replacing the displaced person requires preparation in time and with high expenses of a replacement [33]. It is important to know that any commander needs to be taught what behaviour is expected from him. In general, he is expected to know his subordinates, to communicate the results of their performance assessment, to ask for more, but within the limits of their possibilities and to delegate tasks that are not strictly his 
to carry out [34].

If the results still do not meet either the expectations of the organization or of the military, there are competent specialists that can provide the necessary support. They will work on improving professional aspects, adhering to functional unity standards and correcting deficiencies. Thus, the identity of all the military is strengthened. These specialists can be both military and civilians, and not necessarily psychologists.

\section{References}

[1] Tudosescu, Ion, „Sistemul și tipologia acțiunilor sociale”, în Tudosescu, Ion; Popa, Cornel; Florea, Mihai (coord.), Acțiune, decizie, responsabilitate: studii de praxiologie, București, Editura Academiei, 1978, p. 15.

[2] Tudosescu, Ion, „Sistemul și tipologia acțiunilor sociale”, în Tudosescu, Ion; Popa, Cornel; Florea, Mihai (coord.), Acțiune, decizie, responsabilitate: studii de praxiologie, București, Editura Academiei, 1978, p. 16.

[3] Friedberg, Erhard, „Organizație”, în Boudon, Raymond et. al. (coord.), Dicționar de sociologie, București, Editura Univers Enciclopedic, 1996, p. 197.

[4] Preda, Marian, Comportamentul organizațional: teorii, exerciții și studii de caz, Iași, Editura Polirom, 2006, p. 17.

[5] Moldoveanu, George, Analiză și comportament organizațional, București, Editura Economică, 2005, p. 18.

[6] Hoffman, Oscar; Glodeanu, Ion, „Sociologia organizațiilor”, în Otovescu, Dumitru (coord.), Tratat de sociologie generală, Craiova, Editura Beladi, 2010, p. 895.

[7] Maximilian, Constantin, Geneza individualităţii, București, Editura Sport-Turism, 1980, p. 6.

[8] Maximilian, Constantin, Geneza individualității, București, Editura Sport-Turism, 1980, p. 7.

[9] Maximilian, Constantin, Geneza individualității, București, Editura Sport-Turism, 1980, p. 7.

[10] Maximilian, Constantin, Geneza individualității, București, Editura Sport-Turism, 1980, p. 7.

[11] Maximilian, Constantin, Geneza individualității, București, Editura Sport-Turism, 1980, p. 90 .

[12] Maximilian, Constantin, Geneza individualității, București, Editura Sport-Turism, 1980, p. 90.

[13] Maximilian, Constantin, Geneza individualității, București, Editura Sport-Turism, 1980, p. 92.

[14] Maximilian, Constantin, Geneza individualității, București, Editura Sport-Turism, 1980, p. 132.

[15] Maximilian, Constantin, Geneza individualității, București, Editura Sport-Turism, 1980, p. 95.

[16] Sillamy, Norbert, Dicționar de psihologie, București, Editura Univers Enciclopedic Gold, 2009, p. 224.

[17] Reuchlin, Maurice, „Personalitate”, în Marele dicționar al psihologiei - Larousse, București, Editura Trei, 2006, p. 892.

[18] Golu, Mihai, Bazele psihologiei generale, București, Editura universitară, 2004, p. 659.

[19] Jenkins, Richard, Identitatea socială, București, Editura Univers, 2000, p. 8.

[20] Jenkins, Richard, Identitatea socială, București, Editura Univers, 2000, p. 8.

[21] Jenkins, Richard, Identitatea socială, București, Editura Univers, 2000, pp. 11-12.

[22] Jenkins, Richard, Identitatea socială, București, Editura Univers, 2000, p. 95. 
[23] Jenkins, Richard, Identitatea socială, București, Editura Univers, 2000, p. 97.

[24] Pânișoară, Georgeta, Integrarea în organizații: pași spre un management de succes, Iași, Editura Polirom, 2006, pp. 53-68.

[25] Pânișoară, Georgeta, Integrarea în organizații: pași spre un management de succes, Iași, Editura Polirom, 2006, p. 97.

[26] Preda, Marian, Comportamentul organizațional: teorii, exerciții și studii de caz, Iași, Editura Polirom, 2006, pp. 147-148.

[27] Akerlof, George A.; Kranton, Rachel E., Economia Identității: cum identitatea ne influențează munca, salariile și bunăstarea, București, Editura Publica, 2011, p. 23.

[28] Akerlof, George A.; Kranton, Rachel E., Economia Identității: cum identitatea ne influențează munca, salariile și bunăstarea, București, Editura Publica, 2011, p. 38.

[29] Akerlof, George A.; Kranton, Rachel E., Economia Identității: cum identitatea ne influențează munca, salariile și bunăstarea, București, Editura Publica, 2011, pp. 62-67.

[30] Moldoveanu, George, Analiză și comportament organizațional, București, Editura Economică, 2005, p. 166.

[31] Moldoveanu, George, Analiză și comportament organizaţional, București, Editura Economică, 2005, p. 167.

[32] Horstman, Mark, Managerul eficient, București, Editura Curtea Veche, 2017, p. 8.

[33] Horstman, Mark, Managerul eficient, București, Editura Curtea Veche, 2017, pp. 15-18.

[34] Horstman, Mark, Managerul eficient, București, Editura Curtea Veche, 2017, pp. 19-20. 